\title{
Minimal tillage and intermittent flooding farming systems show a potential reduction in the proliferation of Anopheles mosquito larvae in a rice field in Malanville, Northern Benin
}

Innocent Djègbè ${ }^{1 *}$, Merdie Zinsou $^{2,3}$, Edia Flavien Dovonou ${ }^{2}$, Geneviève Tchigossou $^{3}$, Murielle Soglo $^{3}$, Razack Adéoti ${ }^{3}$, Brice Gbaguidi ${ }^{3}$, Seun Atoyebi ${ }^{3}$, Fabrice Chandre ${ }^{4}$, Martin Akogbéto ${ }^{5}$, Jo Lines $^{6}$ and Rousseau Djouaka ${ }^{3}$

\begin{abstract}
Background: Irrigation systems have been identified as one of the factors promoting malaria disease around agricultural farms in sub-Saharan Africa. However, if improved water management strategy is adopted during rice cultivation, it may help to reduce malaria cases among human population living around rice fields. This study aimed to assess the impact of the different irrigation practices on malaria transmission, as well as to evaluate the water management system that will best mitigate malaria transmission in Malanville, Benin.
\end{abstract}

Methods: Knowledge, Attitude and Practice (KAP) study was conducted on 104 households staying on and around the rice fields in Malanville. The study focused on the frequency of mosquito bites and preventive measures against malaria as well as soil preparation and rice planting methods. Mosquito larvae density was assessed in different water management system: continuous flooding (CF) or intermittent flooding (IF), deep tillage (DT) or minimal tillage (MT) and normal levelling (NL) or abnormal levelling (AL) in an experimental hut set-up. Larvae were collected using dipping methods and their density was determined.

Results: Three tillage systems, which include the use of tiller, plow and hoe, were identified on the rice field. Continuous flooding was the only irrigation system used by farmers. Retrospective data from Malanville Health Centre revealed higher malaria cases during rice production season, which was also confirmed by field participants. The density of Anopheles larvae was reduced by $80.8 \%, 30.8 \%$ and $40.7 \%(P=0.000)$ during transplanting, tillering and maturation periods, respectively with intermittent flooding compared to continuous flooding. In addition, a clear reduction of larva density was observed with both intermittent flooding systems applied to minimal tillage (MT+IF $+N L)$ and intermittent flooding applied to deep tillage (DT $+\mathrm{F}+\mathrm{AL}$ ), showing that intermittent flooding could reduce the abundance of malaria vector in rice fields.

\footnotetext{
*Correspondence: djegbe1@yahoo.fr

${ }^{1}$ National University of Sciences, Technologies, Engineering

and Mathematics, Ecole Normale Supérieure de Natitingou, BP 72,

Natitingou, Benin

Full list of author information is available at the end of the article
}

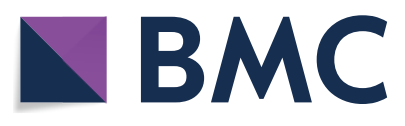

(c) The Author(s) 2020. This article is licensed under a Creative Commons Attribution 4.0 International License, which permits use, sharing, adaptation, distribution and reproduction in any medium or format, as long as you give appropriate credit to the original author(s) and the source, provide a link to the Creative Commons licence, and indicate if changes were made. The images or other third party material in this article are included in the article's Creative Commons licence, unless indicated otherwise in a credit line to the material. If material is not included in the article's Creative Commons licence and your intended use is not permitted by statutory regulation or exceeds the permitted use, you will need to obtain permission directly from the copyright holder. To view a copy of this licence, visit http://creativeco mmons.org/licenses/by/4.0/. The Creative Commons Public Domain Dedication waiver (http://creativecommons.org/publicdomain/ zero/1.0/) applies to the data made available in this article, unless otherwise stated in a credit line to the data. 
Conclusion: Recommending intermittent flooding technology for rice cultivation may not only be useful for water management but could also be an intentional strategy to control mosquitoes vector-borne diseases around rice farms.

Keywords: Malaria, Intermittent flooding, Continuous flooding, Minimal tillage, Deep tillage, Anopheles larvae, Rice field, Malanville

\section{Background}

Malaria is a major health problem in Benin, where it is the main cause of morbidity and mortality particularly among children under five and pregnant women [1]. According to the World Health Organization (WHO), an estimated 219 million cases of malaria occurred worldwide resulting into 435,000 deaths [2].

Benin was enlisted among the 10 highest burdened countries in Africa, with a reported increase of malaria cases in 2017 [2]. Although the vast majority of malaria cases occur in rural areas where agricultural activities are high, most of the developmental interventions in these areas are often towards irrigation project and farming improved practices, with very few intervention studies targeting the agro-ecosystem as a contributing factor to the spread of diseases [3].

Inappropriate practices in agriculture, such as poor irrigation systems and continuous flooding of plots, as well as aggressive land use through excessive tillage have been reported to favour the development of Anopheles mosquitoes and, therefore, worsen the risk of malaria transmission in rice agro-ecosystems throughout Africa [4-6]. Also, there are reports of higher Anopheles mosquito densities in irrigated compared to non-irrigated rice fields [7-9]. The main reason for this assertion is because irrigation systems could, unintentionally, create favourable breeding site for malaria vectors, thereby enabling vector abundance and increasing malaria risks among human populations $[6,10,11]$.

Recent studies conducted in rice fields in Mali and Cameroon showed that excessive tillage increases water beds in agricultural settings and extends the duration of standing water pockets therefore allowing malaria vectors to easily complete their developmental cycles [12, 13]. Their reports further revealed that poor handling of these irrigation systems, such as excess watering and continuous flooding of plots, currently performed by farmers during rice cultivation, can lead to increasing breeding sites for mosquitoes and favour the proliferation of malaria vectors [12]. There are other evidences that have associated rice fields with increased Anopheles gambiae larvae growth and development $[4,7,14]$. This heliophilic species thrives well in shallow, inundated fields during tilling, transplanting, which runs through the first 6 weeks of rice planting (until canopy closure) and after harvest [15]. Similar events have been recorded in Kenya [16, 17], Burkina Faso [18], Gambia [19], Madagascar [20], Senegal [21] and Mali [22].

However, intermittent flooding system that was suggested for rice cultivation requires the release of water to rice fields when needed [23]. This is not only good for water management but also for reducing mosquito proliferation. This system helps to reduce standing waters in rice plots, which minimizes the abundance of mosquito and consequentially lessen malaria risks among human population [24]. A case study in Kenya has already shown that intermittent flooding has the capacity to effectively control the development of Anopheles funestus and Anopheles coustani in rice fields. An alternative system, alternate wetting and drying irrigation (AWDI) cycles coupled with constant cleaning of irrigation canals for efficient water flows can also help to reduce the breeding of malaria vectors. There is a case study in Indonesia showing that a cycle of 9 days wet and 2 days dry in 15 ha field trials reduced the density of the malaria vector Anopheles aconitus by 75\% [24].

Rice is a staple for Africans and its increasing demand means there is need for more production. However, there must be adequate and intentional operations to ensure that increased agricultural activities do not negatively impact other aspects like health and the environment. The negative impact of these operations most times may have effect on the overall social and economic systems.

This study, aimed to investigate common practice in agriculture help in the increased proliferation of malaria vectors specifically, to assess the impact of minimal tillage and intermittent flooding of rice plots on the proliferation of Anopheles mosquitoes and malaria risks in rice agro-eco-systems.

\section{Methods \\ Study site}

The study was conducted from March, 2016 to April, 2017 in the Malanville district $\left(11^{\circ} 52 \mathrm{~N}-3^{\circ} 23 \mathrm{E}\right)$ located in northern Benin (Fig. 1). The district is a rice-growing area that is surrounded by rice farms, particularly towards the North on the right bank of the Niger. The farms are settled on 516 hectares of land that spans through the entire Malanville district that is also a home for more than a million people. Farmers in this farm 


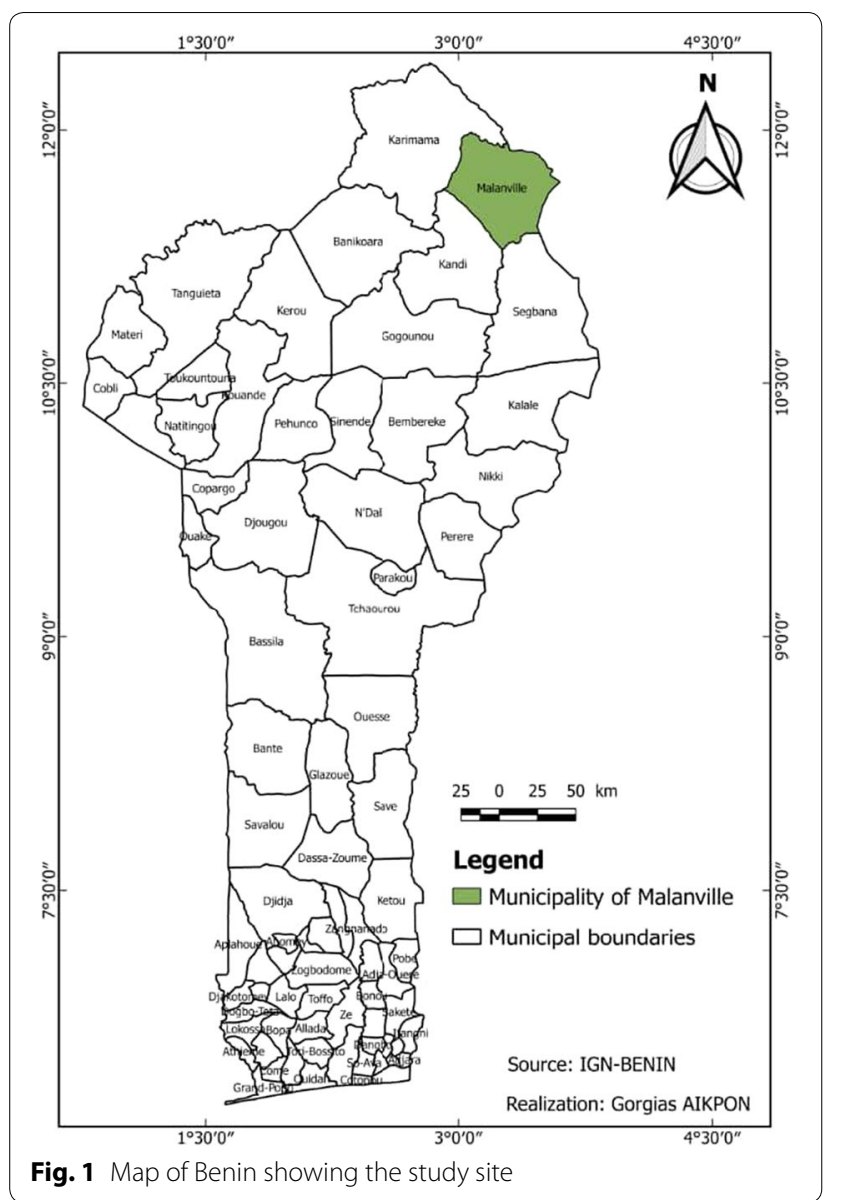

settlement use the continuous flooding with irrigation water pumped directly from the river Niger. Rice cultivation is done throughout the year, which suggests high malaria incidence all year round, due to the continuous flooding system of their rice field [25].

\section{Retrospective clinical malaria data collection}

To assess the impact of irrigation technologies on malaria risk, monthly records of confirmed malaria cases were collected from Malanville Health Centre for 3 years (2013, 2014 and 2015) before this study. The records were sorted out by districts and type of malaria parasite, as confirmed by microscopy. Monthly malaria incidence was calculated for each village to determine their level of malaria transmission in all the months of the year.

\section{Knowledge-attitude-practices (KAP) survey among rice farmers}

This survey was conducted between February and March, 2016. Prior to the commencement of the study, households were randomly selected for inclusion in the study from rosters provided by the president of rice producers.
Voluntary individual farmers (household head) who gave their consent to the study were interviewed using a well-structured questionnaire [26]. Interviews were conducted in private to reduce bias from other members of the community. The languages used for the interviews were French, Hausa and Germa. The questionnaire was administered to know: (i) if local farmers have baseline knowledge on the causes of malaria, (ii) if they know the clinical symptoms of malaria, (iii) if they have any knowledge about mosquito breeding sites and mosquito larvae and (iv) the periods of mosquito abundance in their community.

\section{Investigations on land use, water management and mosquito breeding site identification}

The survey commenced after an ethical clearance $\left(\mathrm{N}^{\circ} 19-21 / 12 / 2015\right)$ was obtained from the Ministry of Health, Benin Republic via le Comité d'Ethique pour la Recherche en Santé of Centre de Recherche Entomologique de Cotonou (CERS-CREC). Also, there was a formal agreement with rice farmers to carry out the study after the aim and objectives of the research have been fully explained and understood. In collaboration with the president of the Rice Farmers' Association (RFA), the full list of farmers in the communities was received. From this list, 32 rice farmers as participants were strategically and randomly selected using some selection criteria, such as farm size (20 rice plots and above), age (20-50 years), gender (male or female).

Information related to soil preparation, tillage equipment and depth (deep, minimal or without tillage on rice field), land levelling after tillage (Normal or abnormal) and water management (types of irrigation system, irrigation scheme, flooding period of rice plots), presence of mosquitoes breeding sites, Anopheles larvae were recorded through direct observation (DO) during periods when farming activities are ongoing. Informations obtained from the DO were further confirmed during focus group discussions with the farmers.

\section{Experimental design}

To access the impact of the new agricultural technologies (minimal tillage and intermittent flooding) on the reduction of Anopheles breeding sites in rice fields, an experimental field of $250 \mathrm{~m}^{2}$ area in the rice field was set aside for the study. On the experimental rice field, rice bins of dimensions, length: $5.5 \mathrm{~m}$; width: $3.0 \mathrm{~m}$; area: $16.5 \mathrm{~m} 2$ was set together with other factors to assess continuous flooding (CF) or intermittent flooding (IF), deep tillage (DT) or minimal tillage (MT) and normal levelling (NL) or abnormal levelling (AL). The minimal tillage means the tillage depth is less than $15 \mathrm{~cm}$ [12]. For intermittent flooding test plots, water was always released into plots 
for 7 days and left for 2 days before being irrigated again. To be sure that this process is followed duly, rice plots racks are opened and closed by farmers under the supervision of a field technician (Additional file 1: Fig. S1). The use of agrochemicals (herbicides, pesticides and insecticides) was avoided by all farmers in both the test and control plots.

Test and control plots were selected alongside with the farm owners and comparison of data obtained was done. In the control plots, farmers used common traditional practices (deep tillage, continuous watering/flooding) while in the test plots a new technology known as minimal tillage and intermittent flooding of plots was used. Five treatments including three test bins and two control bins were done for this comparison. The five treatments were set up with three (3) replicates as shown in Additional file 1: Fig. S2.

- Control bin A1, A2, A3: Plots with conventional system (Deep tillage + Continuous flooding + Abnormal levelling) $\mathrm{DT}+\mathrm{CF}+\mathrm{AL}$.

- Test bin B1, B2, B3: Plots with one of the new technologies introduced (Minimal tillage + Continuous flooding + Abnormal levelling) MT + CF + AL.

- Test bin C1, C2, C3: Plots with one of the new technologies introduced (Deep tillage + Intermittent flooding + Abnormal levelling) DT + IF + AL.

- Control bin D1, D2, D3: Plots with conventional system (Deep tillage + Continuous flooding + Normal levelling) $\mathrm{DT}+\mathrm{CF}+\mathrm{NL}$.

- Test bin E1, E2, E3: Plots with the two new technology introduced (Minimal tillage + Intermittent flooding + Abnormal levelling) MT + IF + AL .

\section{Evaluation of the performance of irrigation technologies on Anopheles larval development in rice farming}

The contribution of minimal tillage and intermittent flooding to the reduction of mosquito larval breeding sites in rice fields was assessed by monitoring mosquito breeding sites. Control and test plots during each developmental stage of rice (transplanting, tillering and maturation) were checked for the presence of water pockets, which could serve as mosquito breeding site by small group of farmers accompanied by an entomologist. Direct observations of mosquito breeding sites, presence of Anopheles mosquito larval, breeding site size, larval development, larval densities and larval persistence were all assessed.

Mosquito larvae were collected from 10 am to $2 \mathrm{pm}$ in the test and control bins during the different stages of rice development using the dipping method [27]. In each plot, 20 scoops were taken using a standard white
$350 \mathrm{ml}$ dipper (ladle). Mosquito larvae collected were identified morphologically using the Gillies and Meillon identification keys and technically recorded based on the collection points [28].

\section{Data analysis}

The total number of mosquito and Anopheles larvae collected per year per bin and rice development stages was recorded in Excel. The significant difference between the type of irrigation system and the density of mosquito larvae was analyzed with ANOVA using XLSTAT software, 2011.

\section{Results}

\section{Knowledge and prevention strategy of malaria by rice farmers from Malanville}

The farmers' knowledge and practices about malaria, including its transmission and preventive measures is presented in Table 1. A total number of 104 households heads were interviewed with $29 \%$ as females while $71 \%$ were males. Malaria $(89.42 \%)$ and schistosomiasis $(27.88 \%)$ were the main diseases observed in Malanville, with over half of the participants, $54.80 \%$ having being earlier sensitized about malaria disease.

The majority (85.57\%) of respondents have adequate understanding that mosquito transmits malaria through bite, although with few misconceptions that are expected. Some believed that drinking dirty water (39.42\%), exposure to the sun (19.23\%), working hard at all times $(15.38 \%)$ or oil consumption $(14.42 \%)$ could also cause malaria. Stagnant water as a main breeding site of mosquitoes was mentioned by $89.42 \%$ of respondents. However, 5 farmers out of 104 (4.80\%) have a prior knowledge that rice growing areas could be a potential mosquito breeding site. Symptoms of malaria such as fever, headache, vomiting and diarrhea were frequently mentioned by farmers. Most of the respondents (91.34\%) did not recognize mosquito larvae. Also, a large number of participants (91.34\%) knew that rainy season and rice cultivation period are proper time for mosquito proliferation.

Strategies used for malaria prevention were the use of insecticidal bed nets (94.23\%), clean the vegetation surrounding the house (85.57\%), mosquito coil (75\%) and insecticide aerosol sprays (17.30\%). About $84.61 \%$ of households declared that they received bed nets from the free distribution campaign organized by the National malaria control program of the Ministry of Health whereas $28.84 \%$ of respondents purchased theirs from local markets. 
Table 1 Farmer's knowledge on malaria

\begin{tabular}{|c|c|c|c|}
\hline Variables & Number & Percentage & $\mathbf{P}$ \\
\hline \multicolumn{4}{|l|}{ Awareness about malaria } \\
\hline Yes & 57 & $54.80 \%$ & \multirow[t]{2}{*}{0.1} \\
\hline No & 47 & $45.20 \%$ & \\
\hline \multicolumn{4}{|c|}{ Diseases suffering by rice farmers } \\
\hline Malaria & 93 & $89.42 \%$ & \multirow[t]{4}{*}{0.001} \\
\hline Yellow fever & 5 & $4.80 \%$ & \\
\hline Schistosomiases & 29 & $27.88 \%$ & \\
\hline Athlete foot & 11 & $10.57 \%$ & \\
\hline \multicolumn{4}{|l|}{ Causes of Malaria } \\
\hline Mosquito bites & 89 & $85.57 \%$ & \multirow[t]{6}{*}{0.001} \\
\hline Hardwork & 16 & $15.38 \%$ & \\
\hline Sun & 20 & $19.23 \%$ & \\
\hline Dirty water consumption & 41 & $39.42 \%$ & \\
\hline Oil consumption & 15 & $14.42 \%$ & \\
\hline Witcheraft & 3 & $2.88 \%$ & \\
\hline \multicolumn{4}{|l|}{ Sign of malaria } \\
\hline Fever & 83 & $79.80 \%$ & \multirow[t]{5}{*}{0.001} \\
\hline Headache & 18 & $17.30 \%$ & \\
\hline Vomiting & 61 & $58.65 \%$ & \\
\hline Diarrhoea & 22 & $21.15 \%$ & \\
\hline Other & 30 & $28.84 \%$ & \\
\hline \multicolumn{4}{|l|}{ Mosquitoes breeding areas } \\
\hline Dirty stagnant water & 93 & $89.42 \%$ & \multirow[t]{4}{*}{0.001} \\
\hline Bushes & 38 & $36.53 \%$ & \\
\hline Rice field & 5 & $4.80 \%$ & \\
\hline Others & 3 & $2.88 \%$ & \\
\hline \multicolumn{4}{|l|}{ Mosquito larvae known } \\
\hline Yes & 9 & $8.65 \%$ & \multirow[t]{2}{*}{0.00001} \\
\hline No & 95 & $91.34 \%$ & \\
\hline \multicolumn{4}{|c|}{ Period of mosquito abundance } \\
\hline Rainy season & 68 & $65.38 \%$ & \multirow[t]{4}{*}{0.01} \\
\hline Dry season & 9 & $8.65 \%$ & \\
\hline During rice cultivation & 59 & $56.73 \%$ & \\
\hline Don't know & 1 & $0.96 \%$ & \\
\hline
\end{tabular}

\section{Impact of irrigation practices in rice field on malaria transmission}

Farmers understand that there is always a rapid increase of mosquito's population during the rice production periods. They were also able to associate the high number of malaria cases occurred in the households during the growing seasons with the rapid increase of mosquito density. Malaria epidemiological data from 2013 to 2015 in Malanville district obtained from the health authority confirmed the farmer's observations (Fig. 2).

The data showed that malaria cases increased during the rainy season and the dry season when intensive rice production is ongoing. The number of malaria cases was highest in the urban centre of Malanville with two peaks. The first peak was in July in all localities and corresponded to the rainy season, while the second one appeared in October and corresponded to the rice irrigation period.

In Malanville centre, malaria cases were highest in October/November, which often coincides with intensive rice production (Fig. 2).

\section{Impact of minimal tillage and intermittent flooding on mosquito larval densities}

During the three developmental stages of rice (transplanting, tillering and maturation) mosquito larvae were collected and the mean densities were compared between tillage and irrigation system. Larval density varied during the three developmental stages of rice; during the transplanting stage, the density of mosquito larvae especially Anopheles larvae was significantly reduced $(\mathrm{P}=0.0000)$ with minimal tillage, intermittent flooding and normal leveling $(\mathrm{MT}+\mathrm{IF}+\mathrm{NL})$ compared to the combination of deep tillage, continuous flooding and abnormal levelling $(\mathrm{DT}+\mathrm{CF}+\mathrm{AL})$. The $\mathrm{MT}+\mathrm{IF}+\mathrm{NL}$ and $\mathrm{DT}+\mathrm{IF}+\mathrm{NL}$ significantly reduced the density of anopheles larvae compared to $\mathrm{MT}+\mathrm{CF}+\mathrm{AL}$, which was more effective larvae reduction compared to $\mathrm{DT}+\mathrm{CF}+\mathrm{NL}$ and $\mathrm{DT}+\mathrm{CF}+\mathrm{AL}$ (Fig. 3). Overall, the MT + IF + NL combination was observed to reduce Anopheles larvae density by 80.83 times $(\mathrm{P}=0.0000)$.

During the tillering stage, $\mathrm{MT}+\mathrm{IF}+\mathrm{PN}$ and $\mathrm{DT}+\mathrm{IF}+\mathrm{AL}$ significantly reduced larval density than $\mathrm{MT}+\mathrm{CF}+\mathrm{AL}, \mathrm{DT}+\mathrm{CF}+\mathrm{NL}$ and $\mathrm{DT}+\mathrm{CF}+\mathrm{AL}$ with $\mathrm{MT}+\mathrm{IF}+\mathrm{PN}$ combination reducing anopheles larva density by 30.88 times during the tillering stage. Similar results were obtained during the maturation stages of rice. The combination of $\mathrm{MT}+\mathrm{IF}+\mathrm{PN}$ reduced larval density by 40.75 times during the maturation (Fig. 3). However, the pattern of levelling did not have any effect $(P>0.05)$ on the reduction of mosquito larvae density during all the developmental stages (Table 2).

\section{Discussion}

Irrigated agriculture is necessary for the expansion of agricultural productivity and to ensure food security. However, irrigation systems have been suggested as one of the contributing factors to increase malaria incidence in many parts of sub-Saharan Africa. The availability of water pockets for mosquito breeding during irrigation appeared to spread the malaria disease and contribute to the extension of disease transmission into the dry season in agricultural areas. However, proper land use and water management, by improving irrigation technologies could help to mitigate this challenge. In the present study, a field experiment was carried out to assess the impact of 

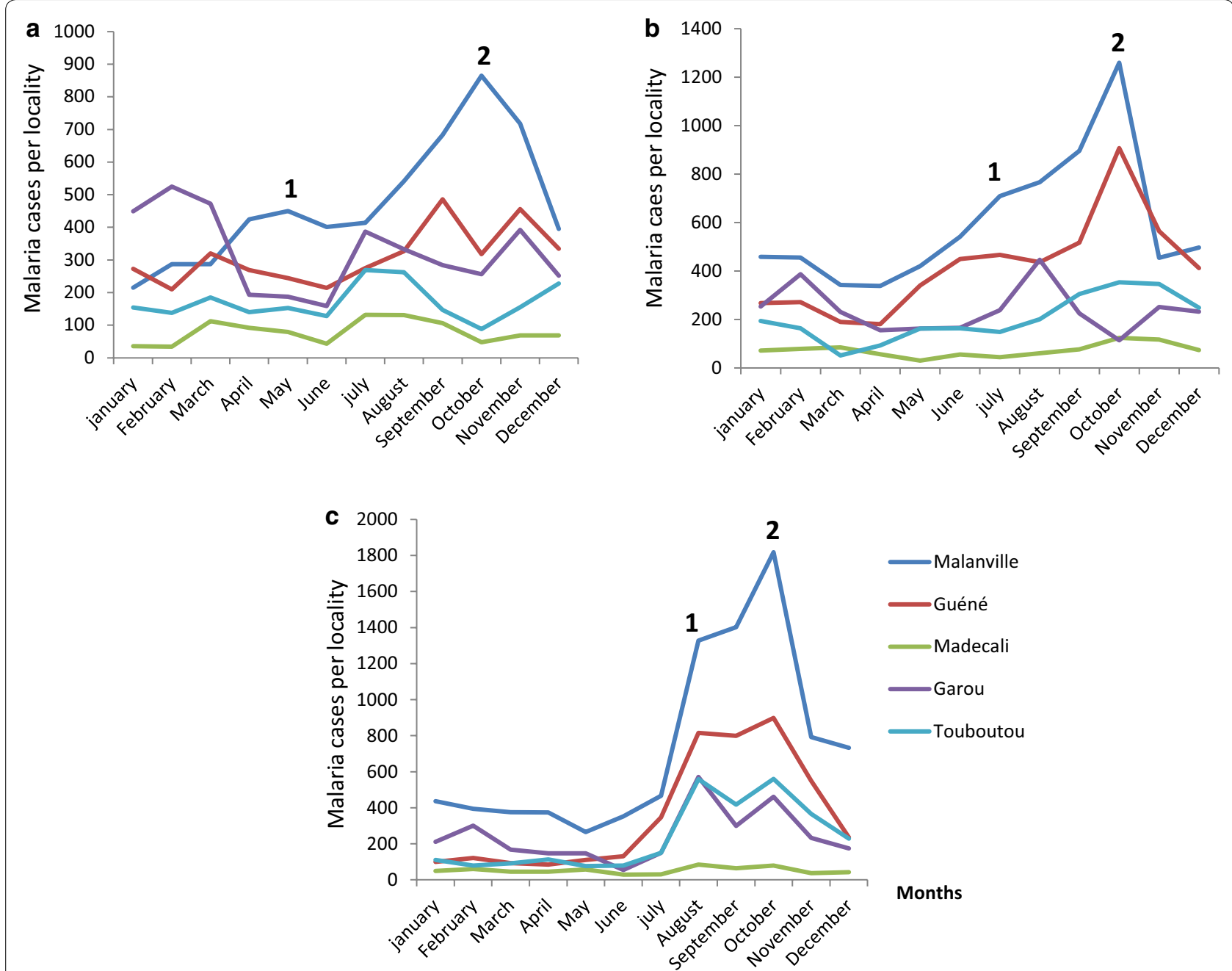

Fig. 2 Malaria cases in Malanville district in 2013 (a), 2014 (b) and in 2015 (c). NB: This figure reveals two peaks of transmission: peak 1 in July due to the rainy season and peak 2 in September due to the rice production and rainfall

land use and water management practices on Anopheles larval density in the rice field at Malanville.

The combination of minimal tillage system with intermittent flooding has a great potential to reduce anopheles breeding sites and larval density in rice fields, as previously observed in other regions in Africa [29-31]. A study conducted in western Ethiopia reported that higher malaria prevalence and transmission risk increased due to high vector abundance in the irrigated sugarcane agroecosystem than non-irrigated agroecosystem [30]. Mutero et al. [32] observed that the use of intermittent flooding in Mwea rice irrigation scheme in Kenya yielded a lower mosquito larval densities and survival. Similarly, Kibret et al. [33] noticed a reduced density of Anopheles in villages where intermittent flooding was used for irrigation in Ethiopia. In China, Qunhua et al. [34] also reported a high reduction of vector breeding below the level required to sustain malaria transmission among individuals in rice field's areas. Furthermore, in 4-year large-scale experiments conducted in Portugal, it was suggested that intermittent flooding of rice fields does not change the quantity or quality of rice yields. On the contrary, increase in yield was reported in some studies, together with a reduction of over $80 \%$ in the number of anopheline larvae [35].

The excessive proliferation of anopheles mosquito vectors due to the type of irrigation system will undoubtedly lead to a higher risk of malaria transmission [31]. Similar concerns were observed from literature where studies have reported a negative impact of some certain practices in Agriculture on the risk of public health diseases [36, 37]. Continuous flooding of rice fields during irrigation was implicated for creating more breeding sites for An. gambiae than normal, 


\section{Panel 1: Transplanting}
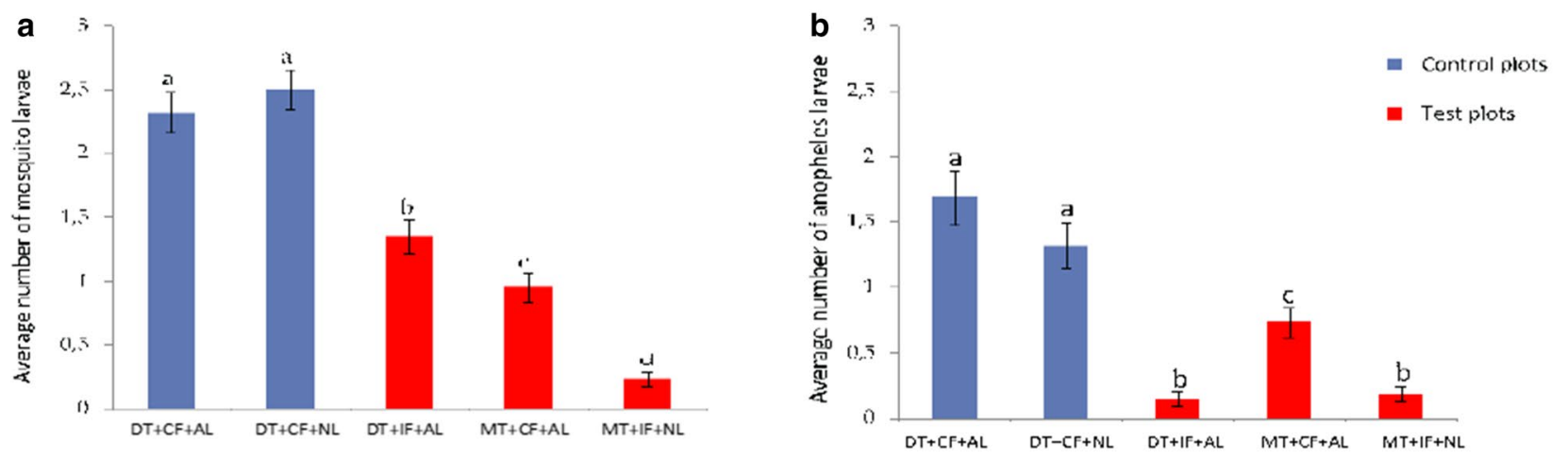

\section{Panel 2: Tillering}
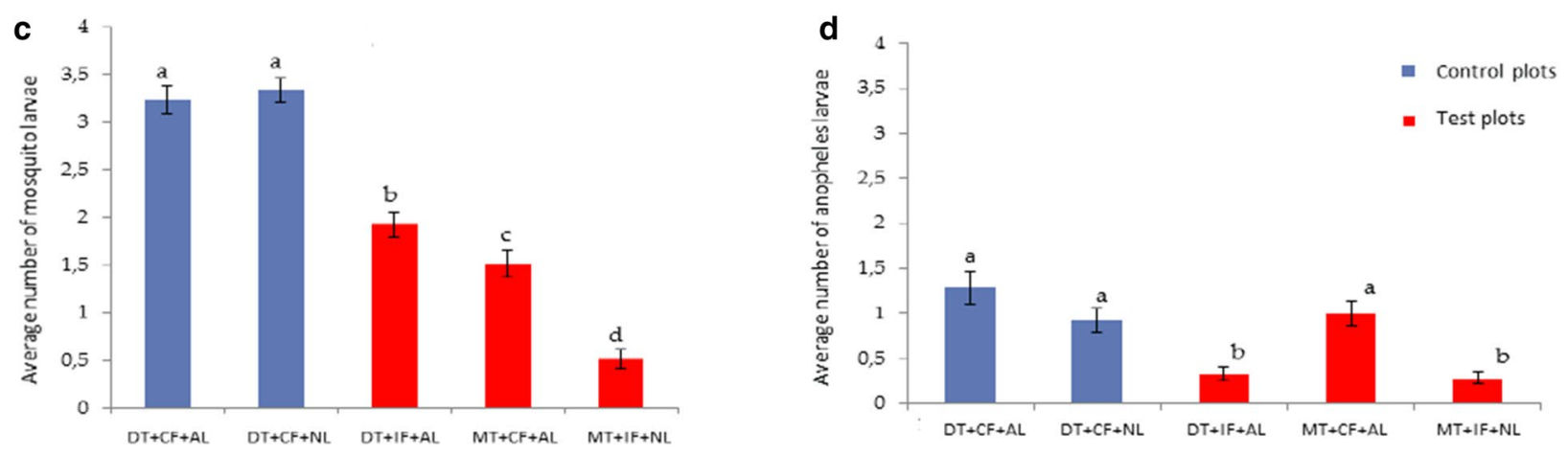

Panel 3: Maturation
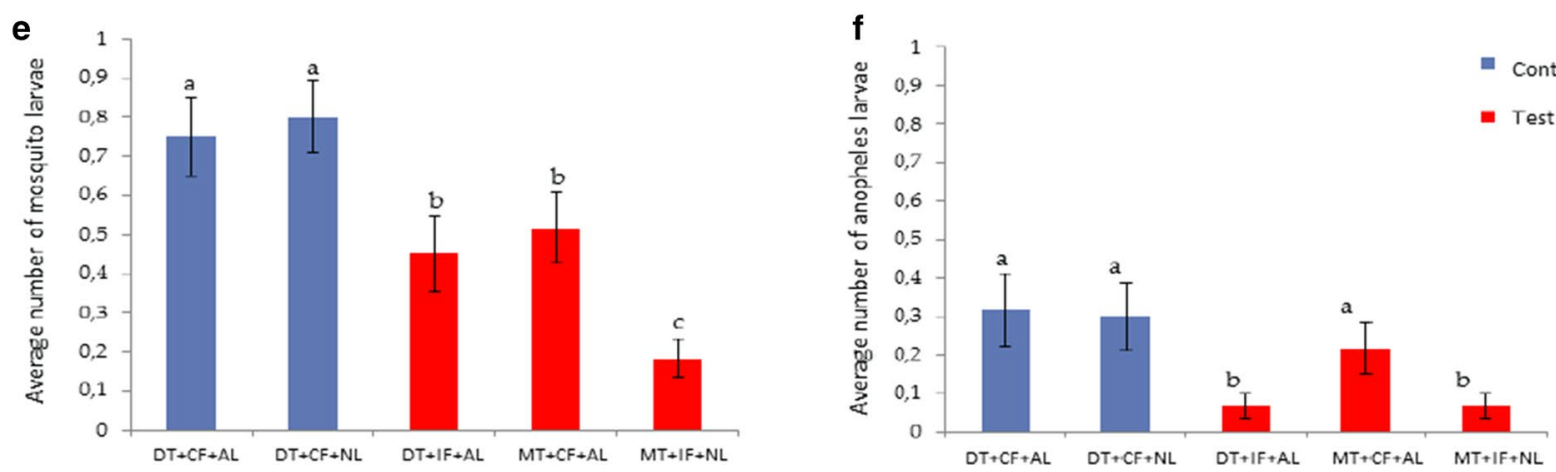

Fig. 3 Mean density of all mosquito larvae and Anopheles mosquito larvae collected during Panel 1 transplanting (a, b), Panel 2 tellering (c, d) and Panel 3 maturation (e, f). NB: DT, Deep tillage; MT, minimal tillage; CF, continuous flooding; IF, intermittent flooding; NL, normal levelling; AL, abnormal levelling. Histogram bars sharing the same letters are not significantly different

which ensured a continual transmission of malaria [36]. A re-orientation and continuous education about this situation are needed so that farmers can know how their activities on the farm can influence and increase the risk of diseases transmission such as malaria and how this will continue if their attitudes towards these are not changed.
Data of malaria cases collected from the health centre at Malanville showed a link between the rice production and the malaria incidence. In Malanville urban centre, locality surrounded by rice farms, the second peak of malaria transmission is not only linked to the end of the rainy season but also and especially to the production of rice. On the other hand, in Guéné, 
Table 2 Mosquito larvae density/350 $\mathrm{ml}$ according to different technologies during rice development

\begin{tabular}{|c|c|c|c|c|c|c|}
\hline & \multicolumn{2}{|l|}{ Tillage } & \multicolumn{2}{|l|}{ Flooding } & \multicolumn{2}{|l|}{ Leveling } \\
\hline & Deep & Minimal & Continuous & Intermittent & Normal & Abnormal \\
\hline Transplanting & $2,056^{\mathrm{a}}$ & $0,592^{b}$ & $1,922^{\mathrm{a}}$ & $0,792^{b}$ & $1,367^{\mathrm{a}}$ & $1,539^{\mathrm{a}}$ \\
\hline$P$ value & 0,000000 & & 0,000000 & & 0,088302 & \\
\hline Tillering & $2,833^{\mathrm{a}}$ & $1,017^{b}$ & $2,694^{\mathrm{a}}$ & $1,225^{b}$ & $1,925^{\mathrm{a}}$ & $2,228^{\mathrm{a}}$ \\
\hline P value & 0,000000 & & 0,000000 & & 0,151127 & \\
\hline Maturation & $0,667^{a}$ & $0,350^{b}$ & $0,689^{a}$ & $0,317^{b}$ & $0,492^{\mathrm{a}}$ & $0,572^{\mathrm{a}}$ \\
\hline$P$ value & 0,001351 & & 0,000065 & & 0,818796 & \\
\hline
\end{tabular}

NB, The numbers sharing the same letter are not significantly different. Comparison was made between deep tillage and minimal tillage, continuous flooding and intermittent flooding, normal levelling and abnormal levelling effect on reduction of anopheles larval density

Garou, Madecali and Touboutou, where there is no rice production, the peak of the disease is only recorded at the end of the rainy season with the availability of water pockets favouring the reproduction of Anopheles.

These observations make continuous farmer's engagement and sensitization on the recognition of various environmental factors involved in the proliferation of mosquitoes in rural communities very important. The type of irrigation systems used in rice fields has been shown to influence increasing abundance of main malaria vector species, An. gambiae sensu lato (s.l.) and An. funestus s.l. [4, 7, 16, 38] and others potential vectors, such as Anopheles pharoensis [4, 33, 39-41], Anopheles rufipes [15, 42, 43], Anopheles ziemanni, frequently found in the irrigation canals of the paddies field [7]. Also, there has been observations of a significant increase of Anopheles densities in irrigated rice field compared to areas with non-irrigated system $[8,44]$. Besides, its contribution to malaria vector abundance has impacted high Anopheles species occurrence, distribution and diversity [16]. Indeed, all stages of rice cultivation (land preparation, nursery preparation, transplanting, fertilizer application, field maintenance, pre-harvesting drainage, and harvesting) were observed to be contributing to this spread.

This cropping cycle also impacted temporal distribution and abundance of malaria vectors. The observed association between continuous flooding and high larval vectors densities compared to intermittent flooding suggests that intermittent flooding should be considered over continuous flooding during rice cultivation. This is not only for the reduction of malaria risks among individuals by minimizing unwanted water$\log$ on/around the farm and halting mosquito larvae developmental stages but also for water management strategy.

Further research is however, necessary to, among other things; determine whether rice yields could be increased by using intermittent flooding in Malanville. It would likewise be important to assess on a wider scale the feasibility of implementing intermittent flooding with respect to farmer acceptance and required changes in irrigation system design and management.

\section{Conclusion}

This study revealed that continuous flooding systems in rice field influences higher proliferation of malaria vectors and consequentially increases the risk of malaria transmission in Malanville district. Instead, an improved irrigation strategy, intermittent flooding, which does not only help to manage water usage but also has the capacity to reduce mosquito breeding sites hence reduces malaria transmission is suggested for use in rice cultivation. While training farmers on how to use intermittent flooding and showing how it will help reduce malaria transmission, it would also be necessary to establish that this alternative method would increase rice yield. This will engender quick and more acceptance of the method, hence, further investigation on rice yield rate of this method at Malanville. This information can be disseminated through organised education programmes for farmers to assist them to check mate all agricultural practices. This will help to prevent unwanted health cases as a result of poor decisions made on the farm in order to reduce larval and adult vector abundance and hence lower the risk of malaria transmission.

\section{Supplementary information}

Supplementary information accompanies this paper at https://doi. org/10.1186/s12936-020-03406-2.

Additional file 1: Figure S1. a) water supply, b) water released from rice plots. Figure S2. Experimental set of rice plots made in the Malanville rice area. Figure S3. Equipment and tillage system in the rice-growing area of Malanville. a: Hoe tillage, b: Plow tillage, c: tillage using tiller. Figure S4. Irrigation systems relying on water storage (a); the channel (b) and the pumping system (c). 


\section{Abbreviations}

DT: Deep tillage; MT: Minimal tillage; CF: Continuous flooding; IF: Intermittent flooding; NL: Normal levelling; AL: Abnormal levelling.

\section{Acknowledgements}

We appreciate Malanville community especially rice farmers for their cooperation and assistance during field work. We thank Eric Tossou and Claude Gande for their technical assistance and relevant advice. We also acknowledge Bernard Bett, Jeff Waage of the Fp5-A4NH.

\section{Authors' contributions}

ID, MA and RD designed the study; MZ; GT; SMA carried out field experiments; ID; MS performed data analysis. ID; GT; MS; SMA wrote the manuscript with contribution from all authors; FED; RA; BG; FC; JL; RD gave advise on the study design and offered significant insight to finalize the manuscript. All authors read, made inputs and approved the final manuscript. All authors read and approved the final manuscript.

\section{Funding}

This work is supported by the WHO/TDR Re-entry grant B40104 awarded to Dr Innocent Djegbe. It also received support from the Fp5-A4NH programme of the CGIAR.

\section{Availability of data and materials}

All data generated and analysed during this study are included in the manuscript and its Additional file 1.

\section{Ethics approval and consent to participate}

Not applicable. However, verbal consent was received from farmers after the study aim and objectives were explained to them.

\section{Consent for publication}

Not applicable.

\section{Competing interests}

The authors declare that they have no competing interests.

\section{Author details}

${ }^{1}$ National University of Sciences, Technologies, Engineering and Mathematics, Ecole Normale Supérieure de Natitingou, BP 72, Natitingou, Benin. ${ }^{2}$ Laboratoire d'Hydrologie Appliquée, University of Abomey-Calavi, Institut National de I'eau, BP 526, Cotonou, Benin. ${ }^{3}$ International Institute of Tropical Agriculture, 08 BP 0932, Cotonou, Benin. ${ }^{4}$ UMR IRD 224-CNRS 5290-Université de Montpellier. MIVEGEC. Maladies Infectieuses et Vecteurs : Ecologie, Génétique, Evolution et Contrôle, 911 Avenue Agropolis, BP 64501, 34394 Montpellier Cedex 5, France. ${ }^{5}$ Centre de Recherche Entomologique de Cotonou (CREC), 06 BP 2604, Cotonou, Benin. ${ }^{6}$ London School of Hygiene and Tropical Medicine, London, UK.

\section{Received: 11 March 2020 Accepted: 4 September 2020}

Published online: 14 September 2020

\section{References}

1. Programme National Malaria Control. Rapport annuel d'activité. Benin: Cotonou; 2012

2. WHO. World Malaria report. Geneva: World Health Organization; 2018.

3. Goonasekere KGA, Amerasinghe FP. Planning, design and operation of irrigation schemes - their impact on mosquito-borne diseases. Vectorborne disease control in humans through rice agroecosystem management. Proceedings Workshop on Research and Training Needs in the field of integrated vector borne diseases control in Rice Agroecosystem of developing countries, 9-14, 1987 International Rice Research Institute, The Philippines 1988. pp. 41-50.

4. Antonio-Nkondjio C, Atangana J, Ndo C, Awono-Ambene P, Fondjo E, Fontenille D, et al. Malaria transmission and rice cultivation in Lagdo, northern Cameroon. Trans R Soc Trop Med Hyg. 2008;102:352-9.

5. Dossou-yovo J, Ouattaraltai A, Doannio J, Diarrassouba S, Chauvancy G. Enquêtes paludométriques en zone de savane humide de Côte d'Ivoire. Med Trop (Mars). 1998;58:51-6.
6. Kibret S, Alemu Y, Boelee E, Tekie H, Alemu D, Petros B. The impact of a small-scale irrigation scheme on malaria transmission in Ziway area. Central Ethiopia. Trop Med Int Health. 2010;15:41-50.

7. Betsi AN, Tchicaya ES, Koudou BG. Forte prolifération de larves d'An. gambiae et An. funestus en milieux rizicoles irrigués et non irrigués dans la region forestière ouest de la Côte-d'Ivoire. Bull Soc Pathol Exot. 2012;105:220-9.

8. Mboera LEG, Bwana VM, Rumisha SF, Stanley G, Tungu PK, Malima RC. Spatial abundance and human biting rate of Anopheles arabiensis and Anopheles funestus in savannah and rice agro-ecosystems of Central Tanzania. Geospat Health. 2015;10:322.

9. Muturi EJ, Muriu S, Shililu J, Mwangangi J, Jacob BG, Mbogo C, et al. Effect of rice cultivation on malaria transmission in Central Kenya. Am J Trop Med Hyg. 2008;78:270-5.

10. Boelee E, Konradsen F, Van Der Hoek W. Malaria in irrigated agriculture: papers and abstracts for the SIMA special seminar at the ICID 18th International congress on irrigation and drainage, Montreal. Colombo: International Water Management Institute; IWMI Working Paper 47; 2002.

11. Muturi E, Shililu J, Jacob B, Gu W, Githure J, Novak R. Mosquito species diversity and abundance in relation to land use in a riceland agroecosystem in Mwea, Kenya. J Vector Ecol. 2006;31:129-37.

12. IPMA/IDRC report Mali. 2012

13. Wiese M. Integrated approaches to malaria control_-addressing new challenges to malaria research. Malar J. 2012;11:104.

14. Diuk-Wasser MA, Touré MB, Dolo G, Bagayoko M, Sogoba N, Sissoko I, et al. Effect of rice cultivation patterns on malaria vector abundance in rice-growing villages in Mali. Am J Trop Med Hyg. 2007;76:869-74.

15. Klinkenberg E, Takken W, Huibers F, Touré YT. The phenology of malaria mosquitoes in irrigated rice fields in Mali. Acta Trop. 2003;85:71-82.

16. Muriu SM, Muturi EJ, Shililu Jl, Mbogo CM, Mwangangi JM, Jacob BG, et al. Host choice and multiple blood feeding behaviour of malaria vectors and other anophelines in Mwea rice scheme, Kenya. Malar J. 2008;7:43.

17. Muturi EJ, Shililu JI, Gu W, Jacob BG, Githure Jl, Novak RJ. Larval habitat dynamics and diversity of Culex mosquitoes in rice agro-ecosystem in Mwea, Kenya. Am J Trop Med Hyg. 2007;76:95-102.

18. Robert V, Gazin P, Boudin C, Molez J, Ouédraogo V, Carnevale P. La transmission du paludisme en zone de savane arborée et en zone rizicole des environs de Bobo-Dioulasso (Burkina Faso). Ann Soc Belge Méd Ttrop. 1985;65:201-14.

19. Lindsay SW, Wilkins HA, Zieler HA, Daly RJ, Petrarca V, Byass P. Ability of Anopheles gambiae mosquitoes to transmit malaria during the dry and wet seasons in an area of irrigated rice cultivation in The Gambia. J Trop Med Hyg. 1991;94:313-24.

20. Marrama L, Jambou R, Rakotoarivony I, Tsi JMLP, Duchemin JB, Laventure $S$, et al. Malaria transmission in Southern Madagascar: influence of the environment and hydro-agricultural works in sub-arid and humid regions: part 1. Entomological investigations. Acta Trop. 2004;89:193-203.

21. Faye O, Gaye O, Fontenille D, Hébrard G, Konate L, Sy N. La sécheresse et la baisse du paludisme dans les Niayes du Sénégal. Cahiers Santé. 1995;5:299-305.

22. Dolo G, Briët OJT, Dao A, Traoré SF, Bouaré M, Sogoba N, et al. Malaria transmission in relation to rice cultivation in the irrigated Sahel of Mali. Acta Trop. 2004;89:147-59.

23. Keiser J, Utzinger J, Singer $\mathrm{BH}$. The potential of intermittent irrigation for increasing rice yields, lowering water consumption, reducing methane emissions, and controlling malaria in African rice fields. J Am Mosq Control Assoc. 2002;18:329-40.

24. Van Der Hoek W, Sakthivadivel R, Renshaw M, Silver J, Birley M, Konradsen F. Alternate wet/dry irrigation in rice cultivation: a practical way to save water and control malaria and Japanese encephalitis? Research Report 47. Colombo: International Water Management Institute; 2001.

25. Corbel V, Chabi J, Dabiré RK, Etang J, Nwane P, Pigeon O, et al. Field efficacy of a new mosaic long-lasting resistant malaria vectors : a multi centre study in Western and Central Africa. Malar J. 2010:9:113.

26. Williams $\mathrm{AH}$, Jones $\mathrm{CO}$. A critical review of behavioral issues related to malaria control in sub-Saharan Africa:what contributionss have social scientists made? Soc Sci Med. 2004;59:501-23.

27. Silver J, Service M. Mosquito ecology: field sampling methods. Dordrecht Springer Publ; 2007. p. 1494 
28. Gillies M, De Meillon B. The Anophelinae of Africa south of the Sahara (Ethiopian zoogeographical region). South African Inst Med Res. 1968;2:101-43.

29. Mutero CM, Blank H, Konradsen F, Van Der Hoek W. Water management for controlling the breeding of Anopheles mosquitoes in rice irrigation schemes in Kenya. Acta Trop. 2000;76:253-63.

30. Jaleta KT, Hill SR, Seyoum E, Balkew M, Gebre-michael T, Ignell R, et al. Agro-ecosystems impact malaria prevalence: large-scale irrigation drives vector population in western Ethiopia. Malar J. 2013:12:350-61.

31. Hawaria D, Demissew A, Solomon K, Lee M-C, Yewhalaw D, Yan G. Effects of environmental modification on the diversity and positivity of anopheline mosquito aquatic habitats at Arjo-Dedessa irrigation development site, Southwest Ethiopia. Infect Dis Poverty. 2020;9:9.

32. Mutero CM, Kabutha C, Kimani V, Kabuage L, Gitau G, Ssennyonga J, et al. A transdisciplinary perspective on the links between malaria and agroecosystems in Kenya. Acta Trop. 2004;89:171-86.

33. Kibret S, Wilson GG, Tekie H, Petros B. Increased malaria transmission around irrigation schemes in Ethiopia and the potential of canal water management for malaria vector control. Malar J. 2014;13:360.

34. Qunhua L, Xin K, Changzhi C, Shengzheng F, Yan L, Rongzhi H, et al. New irrigation methods sustain malaria control in Sichuan Province, China. Acta Trop. 2004;89:241-7.

35. Hill RB, Cambournac FJC. Intermittent irrigation in rice cultivation, and its effect on yield, water consumption and Anopheles production. Am J Trop Med Hyg. 1941;1:123-44.

36. Ijumba JN, Lindsay SW. Impact of irrigation on malaria in Africa: paddies paradox. Med Vet Entomol. 2001;15:1-11.

37. Mboera LEG, Senkoro KP, Mayala BK, Rumisha SF, Rwegoshora RT, Mlozi MRS, et al. Spatio-temporal variation in malaria transmission intensity in five agro-ecosystems in Mvomero district, Tanzania. Geospat Health. 2010;4:167-78.
38. Marrama L, Rajaonarivelo E, Laventure S, Rabarison P. Anopheles funestus et la riziculture sur les plateaux de Madagascar. Cahiers Santé. 1995;5:415-9.

39. Mwangangi J, Shililu J, Muturi E, Gu W, Mbogo C, Kabiru E, et al. Dynamics of immature stages of Anopheles arabiensis and other mosquito species (Diptera: Culicidae) in relation to rice cropping in a rice agro-ecosystem in Kenya. J Vector Ecol. 2006;31:241-5.

40. Kerah-Hinzoumbé C, Péka M, Antonio-Nkondjio C, Donan-Gouni I, Awono-Ambene $P$, Samè-Ekobo A, et al. Malaria vectors and transmission dynamics in Goulmoun, a rural city in south-western Chad. BMC Infect Dis. 2009;9:71.

41. Robert V, van den Broek A, Stevens P, Slootweg R, Petrarca V, Coluzzi M, et al. Mosquitoes and malaria transmission in irrigated rice-fields in the Benoue valley of northern Cameroon. Acta Trop. 1992;52:201-4.

42. Robert V, Verhave JP, Ponnudurai T, Louwe L, Scholtens P, Carnevale P. Study of the distribution of circumsporozoite antigen in Anopheles gambiae infected with Plasmodium falciparum, using the enzyme-linked immunosorbent assay. Trans R Soc Trop Med Hyg. 1988;82:389-91.

43. Sogoba N, Doumbia S, Vounatsou P, Bagayoko MM, Dolo G, Traoré SF, et al. Malaria transmission dynamics in Niono, Mali: the effect of the irrigation systems. Acta Trop. 2007;101:232-40.

44. Mwangangi JM, Shililu J, Muturi EJ, Muriu S, Jacob B, Kabiru EW, et al. Anopheles larval abundance and diversity in three rice agro-village complexes Mwea irrigation scheme, central Kenya. Malar J. 2010;9:228.

\section{Publisher's Note}

Springer Nature remains neutral with regard to jurisdictional claims in published maps and institutional affiliations.
Ready to submit your research? Choose BMC and benefit from:

- fast, convenient online submission

- thorough peer review by experienced researchers in your field

- rapid publication on acceptance

- support for research data, including large and complex data types

- gold Open Access which fosters wider collaboration and increased citations

- maximum visibility for your research: over $100 \mathrm{M}$ website views per year

At BMC, research is always in progress.

Learn more biomedcentral.com/submissions 